\title{
EXPLORING ATOMS AND MOLECULES IN THE CLASSROOM: IS IT POSSIBLE?
}

PROBLEMS

OF EDUCATION

IN THE $21^{\text {st }}$ CENTURY

Vol. 80 , No. 1, 2022

\author{
Solange W. Locatelli \\ Federal University of ABC, Brazil \\ E-mail: solange.locatelli@ufabc.edu.br
}

If you are a chemistry teacher, chances are you have already felt like doing an activity where students could manipulate and explore atoms or molecules in the classroom. Yes, that is right, touching, moving, uniting atoms to form molecules in a classroom, forming the most diverse substances that exist in the world, or at least observing these particles (atoms or molecules) under the microscope, as well as their constituents such as electrons and protons. But, is this possible? It is known that none of this is possible, but it would be desirable if it were, because in this way, students could better understand many phenomena of their daily lives, such as, for example, the burning of coal with the release of gases that, at a submicro level, involves the rearrangement of atoms for the occurrence of such a chemical reaction. Considering this, how to explore the particles in the classroom, which are inaccessible to the human senses, in a way that the student can understand, having an explanation of what is happening macroscopically, that is, of what he or she is observing (seeing) or even feeling, since in this case heat is released. How could we try to explain the natural world, what we experience in our daily lives?

In order to answer this issue, the question that has started this discussion is taken up again, about exploring atoms and molecules in the classroom and it can be said that yes, it is possible, but not directly as we would like it to be possible. Gilbert (2008) states that the elaboration of explanatory models is necessary, in order to help in the understanding of the phenomena of the natural world. These models can be expressed in representational levels, as proposed by Johnstone (1993), and with the following name proposed by Gilbert and Treagust (2009): macro, submicro and symbolic levels. Although other theoretical developments have already been suggested by several researchers (e.g., Talanquer, 2011), expanding this view of representational levels, we still consider the use described above to be fruitful to help students represent and explain a phenomenon of the natural world.

In the example of coal burning, the focus is often on understanding this specific phenomenon and then expanding it, if convenient, necessary, or desirable. Gilbert (2008) refers to "the macroscopic level is therefore a representation of a chunk of the world-as-experience that science is able to explore conveniently" (p. 4).

Continuing with the proposed example, imagine a piece of coal slowly burning, in which the release of gas is observed while this phenomenon occurs, which is called the macro level. Then, this knowledge can be expanded, adding other aspects as proposed by Talanquer (2011), which will help to better understand and characterize this and other levels, such as "different types, scales, dimensions, and approaches of our chemical knowledge" (p. 187). And, finally, maybe even approach, in a qualitative or quantitative way, the triplet components, depending on the need and purpose of what will be discussed in the classroom. In our case, the submicro level can be used, the one that refers to particles, in which a qualitative explanation can be attributed to the phenomenon under observation. An image can be used that will represent a scientifically accepted (very simple) model for burning coal, Figure 1: 
PROBLEMS

OF EDUCATION IN THE $21^{\text {st }}$ CENTURY Vol. 80, No. 1, 2022

Figure 1

Submicro Level Representation of Burning Coal, Gray Balls Corresponding Carbon Atoms and Blue Balls, Oxygen Atoms

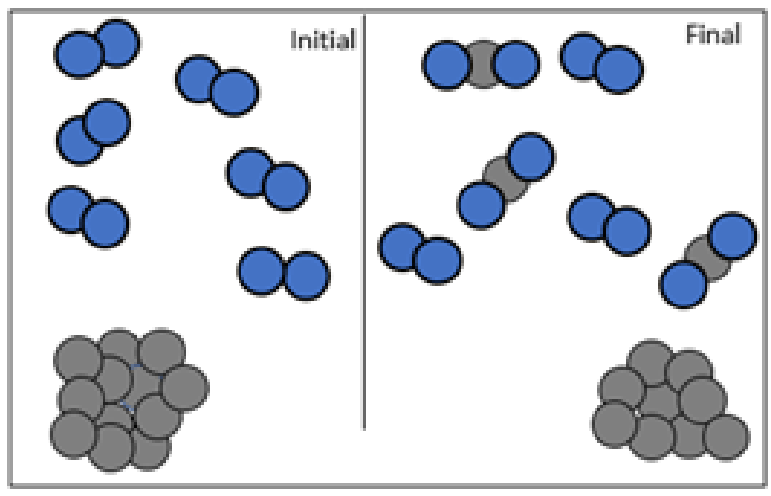

The model represented in Figure 1 was chosen, since it is very simple, and the teacher could use it in the classroom with the students. Thus, when observing the image presented, and at this point it will be very important to make it very clear, they can perceive that it is a representation, or rather, a possibility of representation at a submicro level for the phenomenon, and not the only one. What they are seeing is not a mini-photograph of what happens in the real world, on the contrary, it is an explanatory model, which will help in understanding the phenomenon. Wartha and Rezende (2011) contribute a very interesting idea about the concept of representation in which it "has a long history, which gives it a multiplicity of meanings. In Western philosophy, the idea of representation is linked to the search for appropriate ways to make the 'real' present, to learn it through systems of meaning." (p. 276), since in the case under study, the 'real' cannot be visualized, which would be the carbon atoms interacting with the oxygen gas molecules, in this way explanatory models are used, with their own meaning system, to help us in this task of bringing the 'real' closer to the student.

Regarding the representation at the symbolic level, the following chemical equation can be proposed for this purpose: $\mathrm{C}(\mathrm{s})+\mathrm{O}_{2}(\mathrm{~g}) \rightarrow \mathrm{CO}_{2}(\mathrm{~g})$. In order to prevent it from becoming a mechanical learning, it is necessary for the teacher to discuss the meaning of each representation made, connecting with the macroscopic level that is more accessible and concrete to the student. For the most experienced, it may seem very simple to associate the formula " $\mathrm{O}_{2}$ " with the representation of an oxygen molecule. However, for less experienced students, for example, in basic education, a dialogue discussion with students on this issue is recommended. Why do you write $\mathrm{O}_{2}$ and not $\mathrm{O}$ and $\mathrm{O}$ ? Once in a chemistry class, I myself observed that a couple of students spent about 20 minutes on this discussion of how they should write the representation of an oxygen molecule. This is due to the fact that symbols are loaded with meanings (Taber, 2009), and if this is not clear, learning will be impaired. In this case, it is further added that it is worth noting that the formula " $\mathrm{O}_{2}$ " is not an oxygen molecule, but a representation of an oxygen molecule, and so on. When this dialogic explanation is made, allowing students to expose their previous ideas, this can allow them to rethink about their internal representations, that is, a model that is stored in their memory, on a certain subject. What did he or she imagine the representation of an oxygen molecule would look like? Observing a drawing that the teacher makes on the board, or even an image, will enable monitoring at the meta level that will exercise control at the object level (Nelson \& Narens, 1994). By developing this metavisual skill, the student will become aware of monitoring, controlling the acquisition, retention, retrieval, and modification of an image (Gilbert, 2008). This is reinforced by Locatelli and Davidowitz (2021) who emphasize the importance of metavisualization for the review of chemical concepts, 
metavisualization understood here as a "metavisual skill, where the student will monitor and specifically regulate their internal representations, helping him to build concepts in Science" (Locatelli et al., 2010, p. 76).

Thus, it is presented here, in summary, that it is possible to explore atoms and molecules in the classroom through models and representations. In this way, considering the complexity of the epistemology of chemical knowledge, in which a lot of care is needed on the part of the teacher, taking chemistry to their students in a critical way, developing scientific concepts, which in turn will lead them to become learners metacognitive, with autonomy to learn more and better.

\section{Acknowledgments}

To the São Paulo Research Foundation (FAPESP, 2018/26142-0) for the financing of the research project.

\section{References}

Gilbert, J. K. (2008). Visualization: An emergent field of practice and enquiry in science education. In J. K. Gilbert, M. Reiner, \& M. Nakhled (Eds), Visualization: Theory and practice in science education (pp.3-24). Springer.

Gilbert, J. K., \& Treagust, D. F. (2009). Introduction: Macro, submicro and symbolic representations and the relationship between them: Key models in chemical education. In: Gilbert J. K., \& Treagust, D. (Eds), Multiple representations in chemical education. Models and modeling in science education (Vol 4., pp. 1-8). Springer. https://doi.org/10.1007/978-1-4020-8872-8_1

Johnstone, A. H. (1993). The development of chemistry teaching: A changing response to a changing demand. Journal of Chemical Education, 70(9), 701-705.

Locatelli, S. W., \& Davidowitz, B. (2021). Using metavisualization to revise an explanatory model regarding a chemical reaction between ions. Chemistry Education Research and Practice, 1, 1-14. https://doi.org/10.1039/D0RP00339E

Locatelli, S., Ferreira, C, \& Arroio, A. (2010). Metavisualization: An important skill in the learning chemistry. Problems of Education in the $21^{\text {st }}$ Century, 24, 75-83. http://www.scientiasocialis.lt/ pec/node/441

Nelson, T. O., \& Narens, L. (1994). Why investigate metacognition? In J. Metcalfe \& A. P. Shimamura (Eds.), Metacognition: Knowing about knowing (pp. 1-25). The MIT Press.

Taber, K. S. (2009). Learning at the symbolic level. In: Gilbert, J. K., \& Treagust, D. (Eds), Multiple representations in chemical education. Models and modeling in science education (Vol. 4, pp. 75-104). Springer. https://doi.org/10.1007/978-1-4020-8872-8_5

Talanquer, V.(2011). Macro, submicro, and symbolic: The many faces of the chemistry “triplet". International Journal of Science Education, 33(2), 179-195. https://doi.org/10.1080/09500690903386435

Wartha, E. J., \& Rezende, D. B. (2011). Os níveis de representação no ensino de química e as categorias da semiótica de Peirce [The levels of representation in de teaching of chemistry and the categories of Peirce's semiotics]. Investigações em Ensino de Ciências, 16(2), 275-290. https://www.if.ufrgs. br/cref/ojs/index.php/ienci/article/view/230

Received: January 30, 2022

Accepted: February 15, 2022 
PROBLEMS

OF EDUCATION

IN THE $21^{\text {st }}$ CENTURY

Vol. $80, \frac{1}{8}$

Cite as: Locatelli, S. W. (2022). Exploring atoms and molecules in the classroom: Is it possible? Problems of Education in the $21^{\text {st }}$ Century, 80(1), 5-8. https://doi.org/10.33225/pec/22.80.05 